\title{
EFFECTS OF SMOKING DURING PREGNANCY ON DNA DAMAGE AND ROS LEVEL CONSEQUENCES IN MATERNAL AND NEWBORNS' BLOOD
}

\author{
Umit AYDOGAN ${ }^{1}$, Emre DURMAZ ${ }^{2}$, Cihangir Mutlu ERCAN ${ }^{3}$, Ayse EKEN ${ }^{4}$, Onur Kenan \\ ULUTAS $^{2}$, Serkan KAVUK ${ }^{1}$, Orhan GURSEL ${ }^{5}$, Ibrahim ALANBAY ${ }^{3}$, Cemal AKAY ${ }^{4}$, Ahmet Emin \\ KUREKCI ${ }^{5}$, Ahmet AYDIN ${ }^{6}$, Ahmet SAYAL ${ }^{4}$, Kenan SAGLAM ${ }^{1}$, and Ismet $\mathrm{COK}^{2}$
}

Gulhane Military Medical Academy, Department of Family Medicine, Ankaral', Gazi University, Faculty of Pharmacy, Department of Toxicology, Ankara², Gulhane Military Medical Academy, Department of Obstetrics and Gynecology, Ankara3, Gulhane Military Medical Academy, Department of Toxicology, Ankara4, Gulhane Military Medical Academy, Department of Pediatric Hematology, Ankaras, Yeditepe University, Faculty of Pharmacy, Department of Toxicology, Kayisdagi, Istanbul ${ }^{6}$, Turkey

Received in March 2012

CrossChecked in December 2012

Accepted in October 2012

\begin{abstract}
Some of the genotoxic/carcinogenic substances or metabolites in cigarette smoke are capable of passing through the placenta and harming a newborn's health. Smoking is also known as a factor in the formation of oxidative damage and the main mechanism involved in the carcinogenic process. Predetermining this genotoxic risk can be successfully achieved by measuring certain parameters of oxidative stress. The comet assay is considered an important biomarker for the evaluation of genotoxic substances and is effective for detecting DNA damage caused by smoking. This study examined third trimester bloods and the cord blood of 28 actively smoking and 22 non-smoking mothers in terms of DNA damage and oxidative stress parameters. $\mathrm{Cu} / \mathrm{Zn}$ superoxide dismutase (CuZn-SOD), malondialdehyde (MDA), catalase (CAT), plasma nitrite/nitrates $\left(\mathrm{NO}_{2}{ }^{-} / \mathrm{NO}_{3}{ }^{-}\right.$), selenium-dependent glutathione peroxidase (Se- $\left.\mathrm{GPx}\right), \mathrm{Cu}$, and Zn levels were measured as indicators of oxidative damage. There were no significant increases in DNA damage of the actively smoking pregnant group in comparison with the non-smoking pregnant group, either in the third trimester or cord blood. Oxidative stress parameters of smoker and non-smoker groups were statistically different for MDA $(p<0.05)$, CuZn-SOD $(p<0.01)$, Se-GPx $(p<0.05)$ values while the difference was not significant for $\mathrm{NO}_{2}-\mathrm{NO}_{3}, \mathrm{CAT}, \mathrm{Zn}$, and $\mathrm{Cu}$ values. The same values were also investigated in cord blood, and only $\mathrm{NO}_{2} / \mathrm{NO}_{3}^{-}(p<0.01)$, Se-GPx $(p<0.01$ and CAT $(p<0.001)$ values were found statistically different. Smoking mothers may have been exposed to more oxidative stress than non-smoking mothers.
\end{abstract}

KEY WORDS: cigarette smoke, cord blood, genotoxicity, oxidative stress, pregnant women

It is well-documented that cigarette smoke is a threat to general health with specific and direct consequences in the form of heart and pulmonaryrelated diseases and various cancers (1-3). Apart from the general health effects on adults, it has also been shown that cigarette smoking effects unborn babies, as well as children who are exposed to tobacco smoke as passive smokers (1-3). Epidemiological data $(2,4)$ show that tobacco smoke is associated with detrimental effects on foetal growth, low birth weight and preterm deliveries. It is also known that cigarette smoke may have a role in the aetiology of spontaneous abortions and sudden infant death syndrome (4). 
Except smoking, it is very difficult to single out another form of simultaneous exposure to so many different chemicals. In addition, some substances in cigarette smoke, such as polycyclic aromatic hydrocarbons (PAHs), are known to cause cancer in humans and experimental animals (5). Among these substances are reactive oxygen species (ROS) (5-7). These toxic compounds not only affect adults, but are also able to endanger the health of unborn babies, due to their ability to cross the placenta. As it is known today, in comparison with adults, a foetus is much more sensitive to chemicals (6).

Many of the compounds contained in cigarette smoke are oxidants and pro-oxidants capable of producing ROS. If the amounts of free radicals increase, antioxidant depletion and oxidative stress may occur (8). Tobacco smoking during pregnancy has been reported as one of the source of oxidant status (9). Cigarette smoking can lead to oxidative stress for smokers and those exposed to smoking, as well as reduce the level of certain antioxidants (glutathione, vitamins $\mathrm{E}$ and $\mathrm{C}$, folate and beta-carotene etc.). However, only contradictory findings are available regarding the effects of smoking on dietary antioxidant and oxidant metabolites in pregnant women (10-13).

Even though mothers are aware of the toxicological risks of smoking, it is estimated that $15 \%$ to $20 \%$ of all women smoke during pregnancy (14). Studies conducted on rodents, mammalian cells in culture and in vitro showed that cigarette smoke can induce DNA strand breaks (15-19). Furthermore, human studies also showed that DNA damage is higher in smokers than in non-smokers (20). DNA damage has even been observed in groups that consist of young populations (19 to 23 years old) with a brief history of smoking (21).

Studies have found that there is a relationship between prenatal environmental smoke exposure and neonatal DNA damage (6). The comet assay is a wellestablished and simple technique to determine DNA strand breakage as a sensitive indicator of genetic damage and genotoxicity $(22,23)$. To this day, it has not been reported or discussed that the genotoxicity effects of prenatal smoking exposure on infants was determined by a comet assay.

The aim of the present study was to investigate the genotoxic and oxidative stress parameters that may arise in a pregnant mother and foetus due to the cigarette smoking of the mother. For this purpose, MDA levels and free radical scavenging enzyme activities were measured in blood samples taken from pregnant mothers and umbilical cords and a comet assay was used to investigate the possible genotoxic effects of smoking during pregnancy.

\section{MATERIALS AND METHODS}

\section{Chemicals and media}

Blood collection tubes were obtained from Greiner Bio-one (Kremsmünster, Austria). Fully frosted microscope slides used in the assay were purchased from Menzel GmbH (Braunschweig, Germany). The plastics were acquired from Corning Laboratory Sciences (NY, USA) except for the microtubes, which were purchased from Treff Lab (Degersheim, Switzerland). All chemicals used in this study were of the highest purity available and were purchased from Sigma-Aldrich Chemical (Steinheim, Germany).

\section{Study population}

The study groups consisted of smoking women in their third trimester of pregnancy and their newborns. The participants were volunteers who were smokers and enrolled to the study during their routine controls. Only healthy, non-drug using pregnant women were included in the study. The control group comprised pregnant women under the same criteria, except that these women were not exposed to any tobacco smoke. Mothers who smoked at least 3 cigarettes per day during their pregnancy were regarded as active smokers; only one mother smoked $>10$ cigarettes per day. A total of 50 healthy pregnant women enrolled to our study, 28 of which were active smokers and 22 non-smokers. The mean age for the non-smoking pregnant subjects in the study group was $(28.45 \pm 4.65)$ years (ranged from 20 to 41 years) and (31.32 \pm 4.88$)$ years (ranged from 22 to 40 years) for smoking pregnant mothers.

After receiving a detailed explanation of the study and potential consequences, each participant signed an informed consent form. Each participant completed a detailed health questionnaire to provide details about their smoking habits, medical, family and dietary history including variables known to affect the comet results. The blood samples were collected based on a formal consent form approved by the Ethical Committee of the Gülhane Military Medical Academy (GATA) in Ankara (document number 1491-961- 
09/1539). This study was conducted in accordance with the code of ethics of the Declaration of Helsinki. None of the newborns presented any prenatal or postnatal health problems. Table 1 presents the distribution of the main characteristics of the study populations.

\section{Blood collection}

Following an overnight fast, venous blood samples were collected into heparinized glass tubes containing EDTA in the third trimester of pregnancy during the mothers' regular visits to the hospital for their routine pregnancy control. Three millilitres of blood were collected from the umbilical cord in a heparinized tube immediately after birth for the comet assay. The oxidative stress analysis was performed with the blood collected in EDTA tubes. For this purpose, the blood was centrifuged for $10 \mathrm{~min}$ at $4000 \mathrm{~g}$ and $4{ }^{\circ} \mathrm{C}$. After the separation of plasma, the buffy coat was removed and the packed cells were washed three times with two volumes of isotonic saline. Then, a known volume of erythrocytes was lysed with cold distilled water (1:4), stored in a refrigerator at $4{ }^{\circ} \mathrm{C}$ for $15 \mathrm{~min}$ and the cell debris was removed by centrifugation $(2000$ $g$ at $4{ }^{\circ} \mathrm{C}$ for $\left.10 \mathrm{~min}\right)$. Erythrocyte lysates were stored at $-70^{\circ} \mathrm{C}$ until analysis.

\section{DNA Damage Determination via Comet Assay}

The comet assay was performed under alkaline conditions using an adaptation of the methods described by Singh et al. (22) and Tice et al. (23) with minor modifications. Each step of the experimental study was carried out in a dim and cooled room to minimize any DNA damage. Each analysis was done in duplicate. The phosphate buffered saline (PBS) was used to dilute the collected heparinized blood samples to $1: 10$. Then Histopaque 1077 , which facilitates the recovery of large numbers of viable mononuclear cells, was added to the samples and centrifuged to collect the distinct layer of lymphocytes as a suspension. The
Histopaque 1077 and PBS were precooled on ice. Then $100 \mu \mathrm{L}$ from the collected suspension of lymphocytes were blended with $100 \mu \mathrm{L}$ of $1 \%$ low-melting-point agarose (LMA), overlaid onto precoated slides with $1 \%$ high-melting-point agarose (HMA). In order to solidify the layers of agarose, the microscope slide was refrigerated $\left(4^{\circ} \mathrm{C}\right)$ for $20 \mathrm{~min}$. When the agarose became stiffed, the cover slips were gently removed and the slides were switched into the lysing solution (2.5 mol L-1 $\mathrm{NaCl}, 100 \mathrm{mmol} \mathrm{L}^{-1} \mathrm{Na}_{2}$ EDTA, $10 \mathrm{mmol}$ $\mathrm{L}^{-1}$ Tris-pH 10, $1 \%$ Triton X-100, $10 \%$ DMSO) in the refrigerator $\left(4^{\circ} \mathrm{C}\right.$, overnight $)$. After lysis processes, the slides were initially treated with $1 \mathrm{mmol} \mathrm{L}^{-1}$ $\mathrm{Na}_{2}$ EDTA and $300 \mathrm{mmol} \mathrm{L}^{-1} \mathrm{NaOH}$, (pH 13) for 20 min in an electrophoresis tank, where the slides were randomly placed. Afterward, the tank was set at $25 \mathrm{~V}$ (1.6 $\left.\mathrm{V} \mathrm{cm}^{-1}, 300 \mathrm{~mA}\right)$ for $20 \mathrm{~min}$ at an ambient temperature of $4^{\circ} \mathrm{C}$. Tris buffer $\left(0.4 \mathrm{~mol} \mathrm{~L}^{-1}\right.$ Tris, $\mathrm{pH}$ 7.5) was used to wash the slides (for 5 min each, 3 times, $4^{\circ} \mathrm{C}$ ), before staining them with ethidium bromide. After the staining process, 100 cells were analysed using double slides that were randomly selected for examination under a fluorescent microscope (Zeiss-Axioskop, Oberkochen, Germany) equipped with an excitation filter $515 \mathrm{~nm}$ to $560 \mathrm{~nm}$ and a 100 W Hg lamp. Tail intensity was measured to score DNA damage (\% DNA) using the Comet Assay III image analysis system (Perceptive Instruments, Suffolk, UK). All slides were coded and scored blindly.

\section{Parameters of Oxidative Stress}

Erythrocyte $\mathrm{Cu} / \mathrm{Zn}$ superoxide dismutase $(\mathrm{CuZn}$ SOD), selenium-dependent glutathione peroxidase (Se-GPx), catalase (CAT) activities and malondialdehyde (MDA) and plasma $\mathrm{NO}_{2}{ }^{-} / \mathrm{NO}_{3}^{-}$ levels were measured by using spectrophotometry (UV-2100S, Shimadzu Co., Kyoto, Japan). For CuZnSOD, MDA, Se-GPx activities, zinc and copper concentrations in erythrocytes were determined by methods described by Arsova-Sarafinovska et al. (24).

Table 1 General Characteristics of the Study Population (Mean $\pm S D$ )

\begin{tabular}{lccc}
\hline & Non-smokers $(\boldsymbol{n}=\mathbf{2 2})$ & Smokers $(\boldsymbol{n}=\mathbf{2 8})$ & $\boldsymbol{p}$-value \\
\hline Age $/$ year & $28.45 \pm 4.65$ & $31.32 \pm 4.88$ & $>0.05$ \\
\hline BMI / kg m & 22.74 \pm 2.94 & $23.57 \pm 4.57$ & $>0.05$ \\
\hline BMI at $3^{\text {rd }}$ Trimester $/ \mathrm{kg} \mathrm{m}^{-2}$ & $27.85 \pm 2.65$ & $28.54 \pm 4.16$ & $>0.05$ \\
\hline Birth weights of newborns / g & $3470.45 \pm 452.66$ & $3211.07 \pm 440.29$ & $<0.05$ \\
\hline Duration of Smoking / years & & $9.07 \pm 5.03$ & \\
\hline Number of cigarettes per day & & $5.64 \pm 3.57$ & \\
\hline
\end{tabular}




\section{Cu/Zn superoxide dismutase (CuZn-SOD) activity}

The erythrocyte lysates were diluted 400 -fold with $10 \mathrm{mmol} \mathrm{L}^{-1}$ phosphate buffer $\mathrm{pH} 7.00$. The assay was performed in a buffer solution ( $\mathrm{pH} 10.2)$ containing $50 \mathrm{mmol} \mathrm{L}^{-1}$ (3-(cyclohexylaminol)-1-propanesulfonic acid), $0.05 \mathrm{mmol} \mathrm{L}^{-1}$ xanthine sodium, $0.025 \mathrm{mmol}$ $\mathrm{L}^{-1}$ 2-(4-iodophenyl)-3-(4-nitrophenol)-5phenyltetrazolium chloride (INT), $0.094 \mathrm{mmol} \mathrm{L}^{-1}$ EDTA, and the erythrocyte lysate sample. The reaction was initiated by adding xanthine oxidase $\left(80 \mathrm{U} \mathrm{L}^{-1}\right)$ and the rate of reduction was followed at $505 \mathrm{~nm}$ for $3 \mathrm{~min}$. CuZn-SOD activity was expressed as units per $\mathrm{mL}\left(\mathrm{U} \mathrm{mL}^{-1}\right)$.

\section{Glutathione peroxidase (Se-GPx) activities in erythrocytes}

The reaction mixture was $1 \mathrm{mmol} \mathrm{L}^{-1} \mathrm{Na}_{2} \mathrm{EDTA}$, $4 \mathrm{mmol} \mathrm{L}-1$ sodium azide, $2 \mathrm{mmol} \mathrm{L}^{-1}$ reduced glutathione, $0.2 \mathrm{mM} \mathrm{NADPH}, 1000 \mathrm{U}$ glutathione reductase in $50 \mathrm{mmol} \mathrm{L}^{-1}$ TRIS buffer $\mathrm{pH}$ 7.6, and the sample in $100 \mathrm{mmol} \mathrm{L}^{-1}$ phosphate buffer $\mathrm{pH}$ 7.0. The assay was performed at $37^{\circ} \mathrm{C}$ for $5 \mathrm{~min}$. After adding $8.8 \mathrm{mmol} \mathrm{L}^{-1}$ hydrogen peroxide the reaction was started, and the rate of reduction of NADPH was followed at $340 \mathrm{~nm}$ for $3 \mathrm{~min}$. Se-GPx activity was expressed as $\mathrm{U} \mathrm{mL}^{-1}$.

\section{Erythrocyte catalase (CAT) activity}

CAT activity in erythrocyte haemolysates was measured by the method of Aebi (25). CAT-catalysed decomposition of $\mathrm{H}_{2} \mathrm{O}_{2}$ was directly monitored by measuring the decrease in absorbance at $240 \mathrm{~nm}$ at room temperature for $30 \mathrm{~s}$. One unit of catalase activity is defined as the amount of enzymes that decompose $1 \mu$ mol of $\mathrm{H}_{2} \mathrm{O}_{2}$ per minute under the assay conditions. The results were expressed as $\mathrm{KU} \mathrm{L}^{-1}$.

\section{Malondialdehyde (MDA) quantification}

For determination of quantity of the end-product of lipid peroxidation, MDA were measured as a function of thiobarbituric acid reactive substances (TBARS). Thiobarbituric acid was reacted with malondialdehyde which yielded a fluorescent product gauged spectrophotometrically at $532 \mathrm{~nm}$. The standard used in the assay was tetrametoxypropane and the results were given in $\mathrm{nmol} \mathrm{mL} L^{-1}$.

\section{Plasma $\mathrm{NO}_{2}^{-} / \mathrm{NO}_{3}^{-}$concentrations}

Griess reaction was used to measure plasma $\mathrm{NO}_{2}$ $/ \mathrm{NO}_{3}{ }^{-}$concentrations (26). Briefly, the nitrite/nitrate concentration (nmol $\mathrm{mL}^{-1}$ ) was measured spectrophotometrically at $540 \mathrm{~nm}$ after the plasma samples were incubated with a mixture of reduced nicotine amide adenine dinucleotide phosphate (NADPH), flavin adenine dinucleotide (FAD) and nitrate reductase and Griess reagent (1\% sulphanilamide in $5 \% \mathrm{H}_{3} \mathrm{PO}_{4}$ and $0.1 \% \mathrm{~N}-(1-$ naphtyl)-ethylenediamine, 1:1).

\section{Erythrocyte zinc and copper concentrations}

Zinc and copper concentrations in erythrocyte were determined by flame atomic absorption spectrophotometry (PerkinElmer AAnalyst 800 Atomic Absorption Spectrophotometer, Shelton, CT 06484-4794 USA). The wavelengths of $\mathrm{Zn}$ and $\mathrm{Cu}$ were $213.9 \mathrm{~nm}$ and $324.7 \mathrm{~nm}$, respectively. The concentrations were expressed as micrograms per millilitre $\left(\mu \mathrm{g} \mathrm{mL} \mathrm{m}^{-1}\right)$

\section{Statistical analysis}

Data analyses were performed using Statistical Package for Social Science (SPSS) version 11.5 (SPSS, Chicago, IL). Shapiro-Wilk was used to test normality. Student's t-tests for independent samples and paired samples were applied to test the differences between study groups, while for variables with skewed distributions the Mann-Whitney U-test was performed. Correlations between different variables were analysed by Pearson correlation or Spearman's rank. $P$ value $\leq 0.05$ was considered to be statistically significant.

\section{RESULTS}

The mean values of DNA $\%$ damage (mean $\pm \mathrm{SD}$, tail intensity) in lymphocytes and oxidative stress parameters (mean \pm SD) from study groups are presented in Table 2 and Figure 1. We have not found a significant increase in DNA damage in actively smoking pregnant subjects $(7.76 \pm 2.42) \%$ compared to non-smoking pregnant mothers $(7.39 \pm 1.92) \%$ in their third trimester bloods. No significant difference was found between the groups in comparing cord blood DNA \% damage values of newborns of smoking $(8.59 \pm 2.24) \%$ and non-smoking $(8.57 \pm 1.82) \%$ mothers, as well.

The effects of the duration of smoking and number of cigarettes smoked per day on DNA damage were also investigated on third trimester mothers and cord bloods from foetuses. No statistically significant 
Table 2 The comparison of the values of the conducted oxidative stress tests and the comet assay results.

\begin{tabular}{|c|c|c|c|c|c|c|}
\hline \multirow[b]{2}{*}{ Parameter } & \multicolumn{3}{|c|}{$3^{\text {rd }}$ Trimester - Mother's blood } & \multicolumn{3}{|c|}{ Cord - Child's blood } \\
\hline & $\begin{array}{c}\text { Non-Smoker } \\
(\text { Mean } \pm \text { SD) }\end{array}$ & $\begin{array}{c}\text { Smoker } \\
(\text { Mean } \pm \text { SD })\end{array}$ & $p$-value & $\begin{array}{c}\text { Non-Smoker } \\
(\text { Mean } \pm \text { SD) }\end{array}$ & $\begin{array}{c}\text { Smoker } \\
(\text { Mean } \pm \text { SD) }\end{array}$ & $p$-value \\
\hline $\mathrm{MDA} / \mathrm{nmol} \mathrm{mL} \mathrm{m}^{-1}$ & $29.37 \pm 3.73$ & $32.87 \pm 3.11$ & $<0.05$ & $38.11 \pm 10.83$ & $43.21 \pm 11.25$ & $>0.05$ \\
\hline $\mathrm{NO}_{2}^{-} / \mathrm{NO}_{3}^{-} / \mathrm{nmol} \mathrm{mL}^{-1}$ & $10.67 \pm 2.13$ & $11.47 \pm 2.07$ & $>0.05$ & $4.92 \pm 1.22$ & $6.50 \pm 2.03$ & $<0.01$ \\
\hline $\mathrm{CuZn-SOD} / \mathrm{U} \mathrm{mL}^{-1}$ & $260.05 \pm 49.87$ & $324.75 \pm 60.07$ & $<0.01$ & $357.56 \pm 60.41$ & $360.80 \pm 57.97$ & $>0.05$ \\
\hline Se-GPx / U mL-1 & $14.58 \pm 2.56$ & $16.13 \pm 1.77$ & $<0.05$ & $14.30 \pm 1.72$ & $12.52 \pm 1.87$ & $<0.01$ \\
\hline $\mathrm{CAT} / \mathrm{KU} \mathrm{mL} \mathrm{m}^{-1}$ & $73.14 \pm 10.90$ & $78.37 \pm 7.92$ & $>0.05$ & $75.99 \pm 10.21$ & $64.96 \pm 6.10$ & $<0.001$ \\
\hline $\mathrm{Zn} / \mu \mathrm{g} \mathrm{mL} L^{-1}$ & $7.95 \pm 1.11$ & $7.42 \pm 1.03$ & $>0.05$ & $5.30 \pm 0.79$ & $4.98 \pm 0.66$ & $>0.05$ \\
\hline $\mathrm{Cu} / \mu \mathrm{g} \mathrm{mL} L^{-1}$ & $1.38 \pm 0.19$ & $1.52 \pm 0.27$ & $>0.05$ & $0.79 \pm 0.20$ & $0.93 \pm 0.26$ & $>0.05$ \\
\hline Comet / DNA \% & $7.39 \pm 1.92$ & $7.76 \pm 2.42$ & $>0.05$ & $8.57 \pm 1.82$ & $8.59 \pm 2.24$ & $>0.05$ \\
\hline
\end{tabular}

Table 3 The correlations between the birth weight values and the scores of newborns' and mothers' blood for each applied test.

\begin{tabular}{|c|c|c|c|c|c|c|c|c|c|}
\hline & & MDA & $\mathrm{NO}_{2}^{-} / \mathrm{NO}_{3}^{-}$ & $\begin{array}{l}\text { CuZn- } \\
\text { SOD }\end{array}$ & Se-GPx & CAT & Zn & $\mathrm{Cu}$ & Comet \\
\hline Birth weight & Cor. Coefficient & 0.031 & $-0.335^{a}$ & -0.030 & -0.001 & 0.031 & 0.012 & -0.134 & 0.024 \\
\hline $\begin{array}{l}\text { vs } \\
3^{\text {rd }} \text { trimester } \\
\text { mothers }\end{array}$ & Sig. (2-tailed) & 0.843 & 0.026 & 0.847 & 0.993 & 0.842 & 0.938 & 0.387 & 0.870 \\
\hline \multirow{2}{*}{$\begin{array}{l}\text { Birth weight } \\
\text { vs newborns }\end{array}$} & Cor. Coefficient & 0.130 & -0.131 & 0.288 & 0.152 & 0.089 & 0.037 & 0.020 & 0.010 \\
\hline & Sig. (2-tailed) & 0.395 & 0.390 & 0.055 & 0.318 & 0.559 & 0.810 & 0.894 & 0.942 \\
\hline
\end{tabular}

${ }^{a} p<0.05$

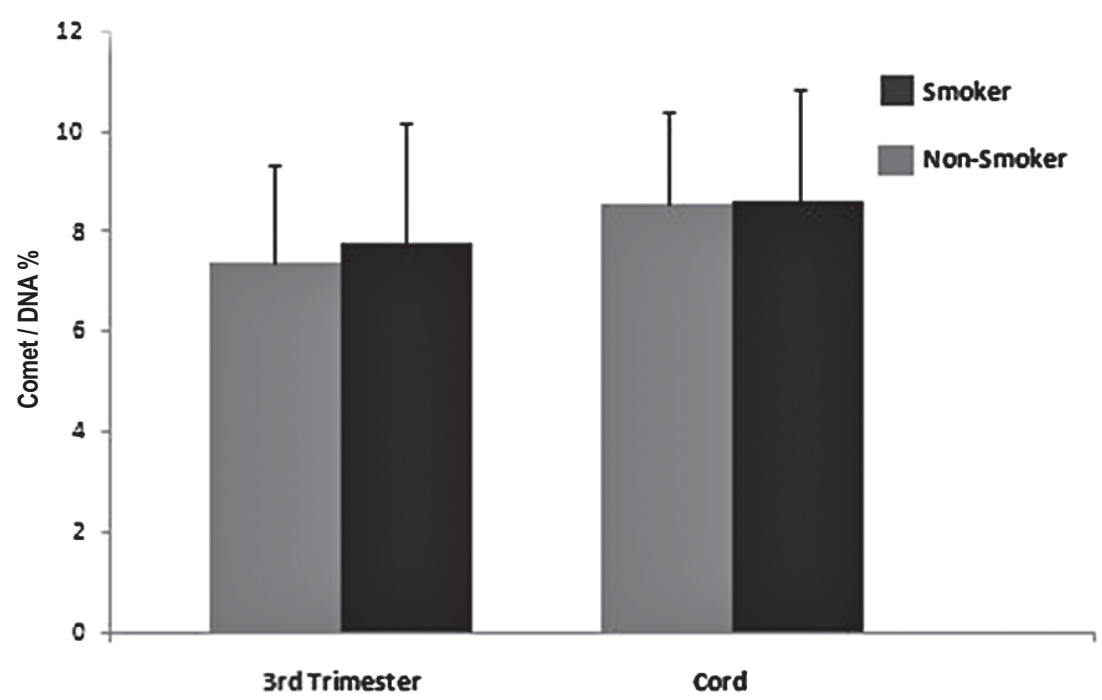

Figure 1 The values of DNA \% damage (mean $\pm S D$, tail intensity) in lymphocytes from mothers and newborns (cord blood).

correlations were found for DNA damage, total time of smoking and number of cigarettes per day, both for the smoking mothers and their newborns. Significant correlations were not found between birth weight of newborns with DNA damage of pregnant women's blood values and newborns' blood values (Table 3). 


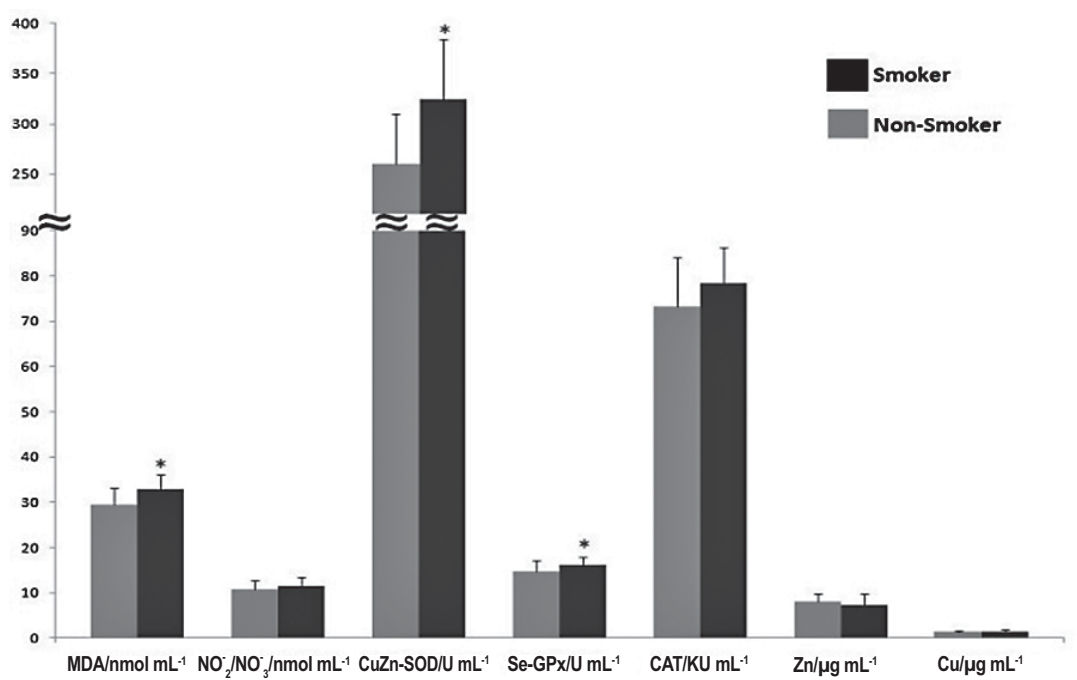

Figure 2 The oxidative stress parameters of smoking mothers in their third trimester.

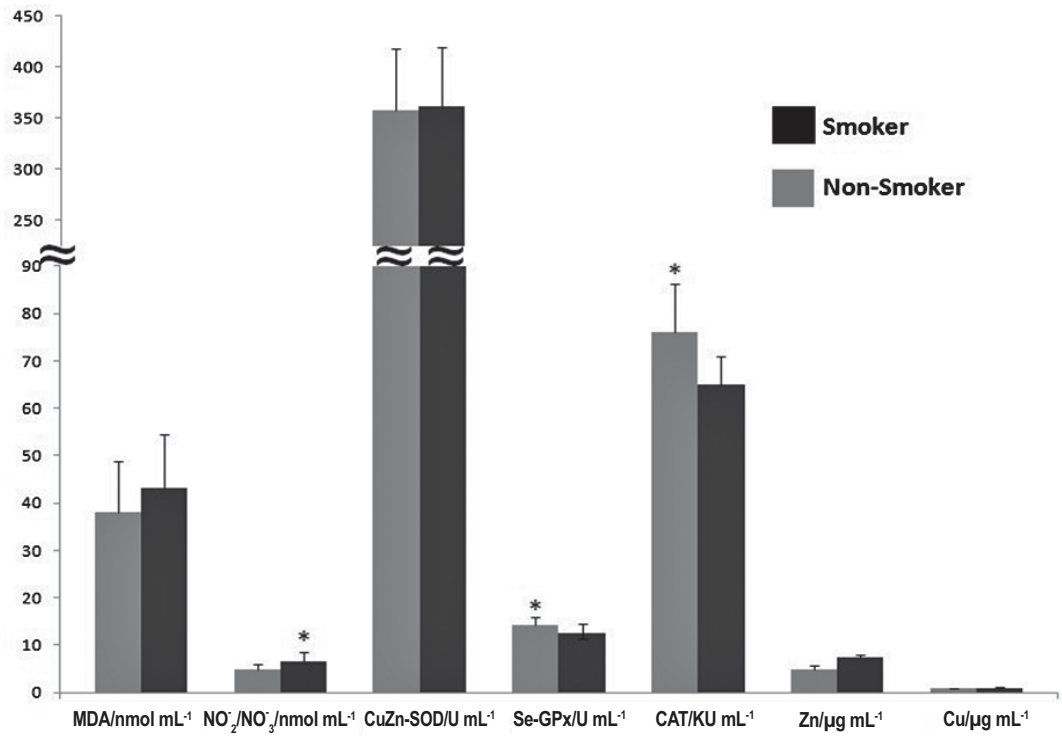

Figure 3 The oxidative stress parameters in cord blood of newborns of smoking mothers.

There were also no significant correlations between DNA damage of mothers and newborns with BMI of mothers in the third trimester. On the other hand, DNA damage showed significant correlation in linear regression analysis between results from non-smoking mothers and their newborns ( $p=0.0001, r=0.66$ ), but indicates non-significant correlation between smokers and their newborns $(p=0.28, r=0.20$ ).

As for the oxidative stress parameters of pregnant mothers' in their third trimester, no difference was found in smoking and non-smoking mothers, except MDA $(p<0.05)$, CuZn-SOD $(p<0.01)$, Se-GPx $(p<0.05)$ values (Figure 2$)$. The same values were also examined in cord blood only for $\mathrm{NO}_{2}^{-} / \mathrm{NO}_{3}^{-}(p<0.01)$,
Se-GPx $(p<0.01)$ and CAT $(p<0.001)$ and were statistically different (Table 2, Figure 3 ).

As for oxidative stress parameters of smoking mothers in their third trimester, we found significant correlations between $\mathrm{NO}_{2}{ }^{-} / \mathrm{NO}_{3}{ }^{-}$and SOD $(p=0.007$, $r=-0.517), \mathrm{NO}_{2}-\mathrm{NO}_{3}$ - and $\mathrm{CAT}(p=0.035, r=-0.415)$, CAT and SOD ( $p=0.012, r=0.484)$. For oxidative stress parameters of cord bloods, significant correlations were found between $\mathrm{NO}_{2}{ }^{-} / \mathrm{NO}_{3}^{-}$and SOD $(p=0.047$, $r=-0.386), \mathrm{NO}_{2}-\mathrm{NO}_{3}{ }^{-}$and Se-GPx $(p=0.035, r=$ $-0.415) \mathrm{NO}_{2}{ }^{-} / \mathrm{NO}_{3}^{-}$and $\mathrm{Zn}(p=0.02, r=-0.446)$.

No significant associations were detected between DNA damage results with erythrocyte CuZn-SOD, Se-GPx, CAT activities, MDA levels, plasma $\mathrm{NO}_{2}^{-} /$ 
$\mathrm{NO}_{3}^{-}$levels and $\mathrm{Cu}, \mathrm{Zn}$ levels of participants, both in smokers or non-smokers. Only $\mathrm{NO}_{2}^{-} / \mathrm{NO}_{3}^{-}(p=0.026$, $r=-0.335)$ levels were correlated with mothers' birth weights, but a similar correlation was not found with birth weight of infants and other oxidative stress parameters (Table 3). $\mathrm{NO}_{2}^{-} / \mathrm{NO}_{3}^{-}$activity was statistically higher in smoking mothers who had a normal vaginal birth $(p=0.048)$.

\section{DISCUSSION}

Epidemiological and toxicological studies suggest that cigarette smoking causes many health problems in adult smokers and the people in their proximity. On the other hand, detailed studies have reported increasingly different types of health risks such as leukaemia or central nervous system tumours in children whose mothers were exposed to cigarette smoke during pregnancy (27-29). The determination of tobacco-specific metabolites in foetal blood and amniotic fluid also supports the possible genotoxic effects of smoking during pregnancy. Meanwhile, some genotoxicity studies $(30,31)$ have demonstrated the existence of an increased incidence of micronuclei and chromosomal aberrations, as well as sister chromatid exchanges in smoking adults; however, only limited data is available on the possible genotoxic risks of smoking on foetuses and newborns.

Previous studies $(3,6,15,20)$ have also discussed this topic and attempted to detect unfavourable consequences. In this context, the comet assay was found to be a useful tool in evaluating the effect of cigarette smoke on DNA damage and was employed in various studies. This method is compatible with other methods used to investigate DNA damage. A meta-analysis of 38 studies on the effects of smoking on peripheral blood cells, determined by means of the comet assay method, demonstrated that smoking does cause DNA damage (20). The controversial results obtained from studies which investigated the genotoxic effects of smoking were attributed to various causes, such as regional, seasonal, genetic and methodological differences $(20,32)$. In our study, tail intensity results were used in the evaluation of DNA damage. The tail intensity $\%$ is a frequently reported parameter in fluorescence measurements by image analysis of cells in the comet assay. The tail intensity \% parameter provides good correlations with the genotoxic agents involved (both exposure time and dose) and genotoxicity seen (break frequency). Therefore, it was the most reliable comet measurement as it is almost unaffected by system settings and may be used for inter-laboratory comparisons (33).

Wu et al. (30) investigated DNA damage only in mothers who were smoking or were exposed to tobacco and found that the levels of DNA damage in smokers and ETS exposed subjects were significantly higher than those of non-smokers. They also concluded that the results of their study suggest that the comet assay is a reliable biomarker for monitoring pregnant women exposed to tobacco smoke which can be used to indicate foetal growth effects from environmental exposure to tobacco smoke (30).

De Assis et al. (3) evaluated active, passive and non-smokers and their respective infants and found that actively smoking mothers have significantly increased DNA damage when compared to mothers who are non- and passive-smokers. On the other hand, considering the evaluated increased DNA damage demonstrated in their study, no difference was found between passive and non-smokers. They noted that newborns of actively smoking mothers also presented higher levels of DNA damage than newborns of passively and non-smoking women. They also added that there was no significant difference detected between the newborns of non-smokers and passivesmokers (3). Actively smoking mothers from this study were heavy smokers, but in our study there were practically no heavy smokers, as the calculated smoking mean was $(6.0 \pm 4.0)$ cigarettes per day. Tsui et al. (6) reported DNA damage in neonates exposed to second-hand smoke through comet analysis. They showed that exposure to tobacco smoke causes higher DNA damages as determined by a comet assay. They also determined that, as the damage increases, newborn birth weight decreases. In our study, cord blood DNA damage levels do not seem to be statistically significantly higher than the DNA damage level of third trimester blood. Also similar to previous studies, we did not observe any correlation between DNA damage and duration of smoking or the number of cigarettes smoked per day $(3,34)$. There was also a significant difference between the birth weights of the control and study groups, but no significant correlation was detected between DNA damage and birth weights.

Oxidative stress is defined as an increased production of oxidants and/or a decrease in the antioxidant capacity $(35,36)$. Miscellaneous types of reactive oxygen (ROS) and reactive nitrogen species (RNS) can be produced which, in interaction with 
DNA and other macromolecules, may form mutagenic lesions. Some physiological and pathological conditions have already been reported to be affected $(24,37)$, including pregnancy and the accompanying complications (9). During pregnancy, the antioxidative defence system is reorganized to restrict oxidative stress (38), while in normal pregnancies oxidative stress parameters and antioxidant protection are known to increase (9). Prohibition of free radical genesis and the inactivation of the already occurred radicals are the main objective of cellular antioxidant defence mechanisms, which includes various enzymatic mechanisms (39). Glutathione peroxidase (GPx), superoxide dismutase (SOD), and catalase (CAT) are important and well-known antioxidant enzyme systems which participate in the endogenous defence system against free radicals $(25,40)$. Cigarette smoking is described in the literature to be a risk factor for the formation of free radicals which may affect pregnant women and their infants. Bolisetty et al. (41) observed increased oxidative stress in pregnant women smokers which resulted in increased vitamin E consumption. Chelchowska et al. (42) found that during pregnancy, SOD enzyme activity increased and was higher by $20 \%$ in the third than in the first trimester. In pregnant smokers, the activity of SOD was higher than in tobacco-abstinent women; however it decreased and was $15 \%$ lower in late pregnancy than in the first trimester. At the beginning of pregnancy, GPx activity was higher in the smoking group than in the non-smoking group. Chelchowska et al. (43) revealed that cigarette smoking increases lipid peroxidation and decreases antioxidant capacity in pregnant women and umbilical cord blood, as they found that endogenous free radical defence system enzyme activities such as CAT, GPx and glutathione reductase were decreased by $30 \%, 15 \%$ and $37 \%$ in smoking pregnant women. In parallel to previous studies $(8,44)$, our study indicates that smoking pregnant women and their newborns have a higher concentration of oxidative stress parameters.

ROS are known to produce membrane peroxidation and MDA formation, which are detrimental to cellular function. Peroxidation may increase membrane permeability, whereas MDA can inactivate membrane transporters by forming intra-and intermolecular cross links. Various studies have shown that smoking induces lipid peroxidation by increasing levels of MDA (45). In the present study, the increases in MDA levels were comparable to previous results. We confirmed that increased MDA levels in pregnant women may suggest that cigarette smoking triggers lipid peroxidation.

High amounts of polyunsaturated fatty acids in the placenta provide protection from the lipid-peroxides secreted from maternal circulation. During pregnancy, placental lipid products are known to be regulated by placental antioxidant enzymes (46). This study found a significant difference in catalase levels between the control group and the smoker groups. Even though we observed an increase in activities of SOD and GPx, a compensatory increase in the level of CAT was not detected. We interpreted this as a protective role of the placenta, while the oxidative stress due to smoking may have been effectively kept under control by SOD and GPx. SOD, which catalyses the transformation of superoxide free radicals into hydrogen peroxide and molecular oxygen, and GPx, which limits lipid peroxidation and uses glutathione as a cofactor, are the two major enzymes involved in the antioxidant system. Some studies have shown that serum SOD and GPx activity is lower in smokers than in nonsmokers $(47,48)$. On the other hand, there are also studies that show no relationship $(9,49,50)$ or increased antioxidant activity $(51,52)$. In the present study, the analysis of SOD and GPx blood levels in the third trimester of pregnant women revealed them to be significantly higher in smoking women. Our findings are parallel to the results of previous studies $(51,52)$.

Cigarette smoking is also known to be a risk factor for endothelial dysfunction (53). The nitric oxide radical (NO) is a highly unstable oxidative radical with a very short half-life which originates from the endothelium. Plasma concentrations of $\mathrm{NO}_{2}{ }^{-} / \mathrm{NO}_{3}{ }^{-}$are used to determine $\mathrm{NO}$ formation (25). However, excess NO may cause cytotoxic and cytostatic effects $(54,55)$. Many studies in non-pregnant women concerning endothelium-dependent vasodilatation suggest that the reduced production of the vasodilator nitric oxide (NO) is instrumental in the reduced flow caused by smoking. NO also has other homeostatic functions in the foetus; impaired vasodilatation may not be the only mechanism restricting foetal growth in smokers (50). In our study, we analysed the concentration of $\mathrm{NO}_{2}^{-} / \mathrm{NO}_{3}{ }^{-}$and found that only the newborns of smoking mothers' revealed significantly elevated cord blood values. Reduced production of NO in foetal vessels in pregnant smokers may lessen blood flow to the foetus and result in lower birth weight, length, and head circumstances $(56,57)$. Andersen and co-workers (51) claimed that smoking 
during pregnancy reduces endothelial nitric oxide synthase (eNOS) activity in the foetal vascular vessels, which contributes to foetal growth retardation caused by the decreased vasodilatation. $\mathrm{NO}_{2}^{-} / \mathrm{NO}_{3}$ activity was determined to be higher in pregnant women who had a normal vaginal birth compared to those who had a caesarean delivery. This finding suggests that vaginal delivery increases oxidative stress to a greater extent. In a study realized by Dani et al. (58), $\mathrm{NO}_{2}^{-} / \mathrm{NO}_{3}^{-}$activity was determined to be higher in term normal vaginal birth babies than in elective caesarean delivery babies, while $\mathrm{NO}_{2}^{-} / \mathrm{NO}_{3}^{-}$ activity decreased in $48 \mathrm{~h}$ to $72 \mathrm{~h}$ after birth. $\mathrm{NO}_{2}^{-} / \mathrm{NO}_{3}{ }^{-}$ activity which we determined in the cord blood of pregnant women who had a normal vaginal delivery was found to be consistent with the literature.

The lack of zinc $(\mathrm{Zn})$ and copper $(\mathrm{Cu})$ contributes to tissue damage as an acute reaction (59). Some researchers noted decreased $\mathrm{Zn}$ levels in contrast to increased $\mathrm{Cu}$ concentrations in smokers $(47,60)$. Hulea et al. (47) reported that erythrocyte $\mathrm{Cu}-\mathrm{Zn}$-SOD activity was lower in adult cigarette smokers than non-smokers. Although the $\mathrm{Zn}$ levels were lower and the $\mathrm{Cu}$ levels were higher, a statistically significant relationship could not be established between $\mathrm{Zn}$ and $\mathrm{Cu}$ levels. The increased antioxidant activity caused by pregnancy may result from the levels of these elements.

In conclusion, there were no statistically significant increases of DNA damage in the actively smoking pregnant group when compared to the non-smoking pregnant group, either in the third trimester or cord blood, although other oxidative stress parameters in pregnant smokers were found to be increased. There were significant increases in enzyme activities and MDA levels of smoking mothers, suggesting that they may have been exposed to more oxidant stress than non-smoking mothers. For this reason, cigarette smoking during pregnancy may activate free oxygen radical damage to the mother. We can certainly conclude that quitting smoking early on in the pregnancy may avoid harmful effects on the newborn.

\section{Acknowledgements}

The authors wish to thank all the subjects who volunteered to participate. This study was supported by the Gazi University Research Foundation (Grant no: 02/2011-15).

\section{REFERENCES}

1. Katić J, Fučıć A, Gamulin M. Prenatal, early life, and childhood exposure to genotoxicants in the living environment. Arh Hig Rada Toksikol 2010;61:455-64.

2. Boffetta P, Trédaniel J, Greco A. Risk of childhood cancer and adult lung cancer after childhood exposure to passive smoke: A Meta-Analysis. Environ Health Perspect 2000;108:73-82.

3. de Assis KR, Ladeira MS, Bueno RC, Dos Santos BF, Dalben I, Salvadori DM. Genotoxicity of cigarette smoking in maternal and newborn lymphocytes. Mutat Res 2009;679:728 .

4. Shea AK, Steiner M. Cigarette smoking during pregnancy. Nicotine Tob Res 2008;10:267-78.

5. Fowles J, Dybing E. Application of toxicological risk assessment principles to the chemical constituents of cigarette smoke. Tob Control 2003;12:424-30.

6. Tsui H, Wu HI, Lin C, Wang R, Chiu H, Cheng Y, Chiu T, Wu F. Prenatal smoking exposure and neonatal DNA damage in relation to birth outcomes. Pediatr Res 2008;64:131-4.

7. Adenuga D, Rahman I. Oxidative stress, histone deacetylase and corticosteroid resistance in severe asthma and COPD. Curr Res Med Rev 2007;3:57-68.

8. Aycicek A, Ipek A. Maternal active or passive smoking causes oxidative stress in cord blood. Eur J Pediatr 2008;167:815 .

9. Ermis B, Ors R, Yildirim A, Tastekin A, Kardas F, Akcay F. Influence of smoking on maternal and neonatal serum malondialdehyde, superoxide dismutase, and glutathione peroxide levels. Ann Clin Lab Sci 2004;34:405-9.

10. Orhon FS, Ulukol B, Kahya D, Cengiz B, Başka S, Tezcan $\mathrm{S}$. The influence of maternal smoking on maternal and newborn oxidant and antioxidant status. Eur J Pediatr 2009;168:975-81

11. Northrop-Clewes CA, Thurnham DI. Monitoring micronutrients in cigarette smokers. Clin Chim Acta 2007;377:14-38.

12. Songül Şahinli A, Marakoğlu K, Kiyici A. Evaluation of the levels of oxidative stress factors and ischemia modified albumin in the cord blood of smoker and non-smoker pregnant women. J Matern Fetal Neonatal Med 2012;25:1064-

13. Lee BM, Lee SK, Kim HS. Inhibition of oxidative DNA damage, 8-OHdG, and carbonyl contents in smokers treated with antioxidants (vitamin $\mathrm{E}$, vitamin $\mathrm{C}$, beta-carotene and red ginseng). Cancer Lett 1998;132:219-27.

14. Bruin JE, Gerstein HC, Holloway AC. Long-term consequences of fetal and neonatal nicotine exposure: a critical review. Toxicol Sci 2010;116:364-74.

15. DeMarini DM. Genotoxicity of tobacco smoke and tobacco smoke condensate: a review. Mutat Res 2004:567:447-74.

16. Yang Q, Hergenhahn M, Weninger A, Bartsch H. Cigarette smoke induces direct DNA damage in the human B-lymphoid cell line Raji. Carcinogenesis 1999;20:1769-75.

17. Fielding S, Short C, Davies K, Wald N, Bridges BA, Waters R. Studies on the ability of smoke from different types of cigarettes to induce single-strand breaks in cultured human cells. Mutat Res 1989;214:147-51.

18. Nakayama T, Kaneko M, Kodama M, Nagata C. Cigarette smoke induces DNA single-strand breaks in human cells. Nature 1985;314:462-4 
19. Leanderson P, Tagesson C. Cigarette smoke-induced DNA damage in cultured human cells: role of hydroxyl radicals and endonuclease activation. Chem Biol Interact 1992;81:197208.

20. Hoffmann H, Högel J, Speit G. The effect of smoking on DNA effects in the comet assay: a meta-analysis. Mutagenesis 2005;20:455-66.

21. Ellahueñe MF, Pérez-Alzola LP, Farfán-Urzua M, GonzálezHormazabal P, Garay M, Olmedo MI, Last JA. Preliminary evaluation of DNA damage related with the smoking habit measured by the comet assay in whole blood cells. Cancer Epidemiol Biomarkers Prev 2004;13:1223-9.

22. Singh NP, Mccoy MT, Tice RR, Schneider EL. A simple technique for the quantitation of low levels of DNA damage in individual cells. Exp Cell Res 1998;175:184-91.

23. Tice RR, Agurell E, Anderson D, Burlinson B, Hartmann A, Kobayashi H, Miyamae Y, Rojas E, Ryu JC, Sasaki YF. Single cell gel/comet assay: guidelines for in vitro and in vivo genetic toxicology testing. Environ Mol Mutagen 2000;35:206-21.

24. Arsova-Sarafinovska Z, Eken A, Matevska N, Erdem O, Sayal A, Savașer A, Banev S, Petrovski D, Dzikova S, Georgiev V, Sikole A, Özgök Y, Suturkova L, Dimovski AJ, Aydın A. Increased oxidative/nitrosative stress and decreased antioxidant enzyme activities in prostate cancer. Clin Biochem 2009;42:1228-35.

25. Aebi H. Catalase in vitro. Methods Enzymol 1984;105:1216.

26. Tracey WR, Tse J, Carter G. Lipopolysaccharide-induced changes in plasma nitrite and nitrate concentrations in rats and mice: pharmacological evaluation of nitric oxide synthase inhibitors. J Pharmacol Exp Ther 1995;272:1011-5.

27. Mucci LA, Granath F, Cnattingius S. Maternal smoking and childhood leukemia and lymphoma risk among 1,440,542 Swedish children. Cancer Epidemiol Biomarkers Prev 2004:13:1528-33.

28. Sasco AJ, Vainio H. From in utero and childhood exposure to parental smoking to childhood cancer: a possible link and the need for action. Hum Exp Toxicol 1999;18:192-201.

29. Filippini G, Farinotti M, Ferrarini M. Active and passive smoking during pregnancy and risk of central nervous system tumors in children. Paediatr Perinat Epidemiol 2000;14:7884.

30. Wu FY, Wu HD, Yang HL, Kuo HW, Ying JC, Lin CJ, Yang CC, Lin LY, Chiu TH, Lai JS. Associations among genetic susceptibility, DNA damage, and pregnancy outcomes of expectant mothers exposed to environmental tobacco smoke. Sci Total Environ 2007;386:124-33.

31. DeMarini DM, Preston RJ. Smoking while pregnant: transplacental mutagenesis of the fetus by tobacco smoke. JAMA 2005;293:1264-5.

32. Hoffmann H, Isner C, Högel J, Speit G. Genetic polymorphisms and the effect of cigarette smoking in the comet assay. Mutagenesis 2005;20:359-64.

33. Collins AR. The comet assay for DNA damage and repair: principles, applications, and limitations. Mol Biotechnol 2004;26:249-61.

34. Møller P, Knudsen LE, S Loft, Wallin H. The comet assay as a rapid test in biomonitoring occupational exposure to DNA-damaging agents and effect of confounding factors Cancer Epidemiol Biomarkers Prev 2000;9:1005-15.

35. Baykal Y, Yilmaz MI, Celik T, Gok F, Rehber H, Akay C, Kocar IH. Effects of antihtpertensive agents, alpha receptor blockers, beta blockers, angiotensin-converting enzyme inhibitors, angiotensin receptor blockers and calcium channel blockers, on oxidative stres. J Hypertens 2003;21:1207-11.

36. Gumus S, Yucal O, Gamsizkan M, Eken A, Deniz O, Tozkoparan E, Genc O, Bilgic H. The role of oxidative stres and effect of alpha-lipoic acid in reexpansion pulmonary edema-an experimental study. Arch Med Sci 2010;6:84853.

37. Yasar M, Yıldız S, Mas R, Dundar K, Yıldırım A, Korkmaz A, Akay C, Kaymakcıoglu N, Ozısık T, Sen D. The effect of hyperbaric oxygen treatment on oxidative stres in experimental acute necrotizing pancreatitis. Physiol Res 2003;52:111-6.

38. Gitto E, Reiter RJ, Karbownik M. Causes of oxidative stress in the pre-and perinatal period. Biol Neonate 2002;81:14657

39. Yorbik O, Sayal A, Akay C, Akbiyik DI, Sohmen T. Investigation of antioxidant enzymes in children with autistic disorder. Prostaglandins Leukot Essent Fatty Acids 2002;67:341-3.

40. Bolcal C, Yıldırım V, Doğancı S, Sargın M, Aydın A, Eken A, Özal E, Kuralay E, Demirkılıç U, Tatar H. Protective effects of antioxidant medications on limb ischemia reperfusion injury. J Surg Res 2007;139:274-9.

41. Bolisetty S, Naidoo D, Lui K, Koh TH, Watson D, Montgomery R, Whitehall J. Postnatal changes in maternal and neonatal plasma antioxidant vitamins and the influence of smoking. Arch Dis Child Fetal Neonatal Ed 2002;86: F36-40.

42. Chelchowska M, Laskowska-Klita T, Niemiec KT. [Activities of superoxide dismutase, glutathione peroxidase and catalase in erythrocytes of women smoking during pregnancy, in Polish]. Przegl Lek 2005;62:1039-42.

43. Chelchowska M, Laskowska-Klita T, Leibschang J. [Activities of superoxide dismutase, catalase, glutathione peroxidase and reductase in umbilical cord blood of newborn from mothers smoking during pregnancy, in Polish]. Przegl Lek 2006;63:970-3.

44. Schwarz KB, Cox JM, Sharma S, Clement L, Witter F, Abbey H, Sehnert SS, Risby TH. Prooxidant effects of maternal smoking and formula in newborn infants. J Pediatr Gastroenterol Nutr 1997;24:68-74.

45. Serdar Z, Dirican M, Serdar A, Sarandöl E, Yeşilbursa D, Tokullugil A. Investigation of the effects of smoking on lipid peroxidation and antioxidants in patients with coronary artery disease. Türkiye Klinikleri, J Med Sci 1999;19:266-74.

46. Walsh SW, Wang Y. Secretion of lipid peroxides by the human placenta. Am J Obstet Gynecol 1993;169:1462-6.

47. Hulea SA, Olinescu R, Nita S, Crocnan D, Kummerow FA. Cigarette smoking causes biochemical changes in blood that are suggestive of oxidative stress: a case-control study. J Environ Pathol Toxicol Oncol 1995;14:173-80.

48. Kim SH, Kim JS, Shin HS, Keen CL. Influence of smoking on markers of oxidative stress and serum mineral concentrations in teenage girls in Korea. Nutrition 2003;19:240-3.

49. Wurzel H, Yeh CC, Gairola C, Chow CK. Oxidative damage and antioxidant status in the lungs and bronchoalveolar lavage fluid of rats exposed chronically to cigarette smoke. J Biochem Toxicol 1995;10:11-7.

50. Gupta MP, Khanduja KL, Sharma RR. Effect of cigarette smoke inhalation on antioxidant enzymes and lipid peroxidation in the rat. Toxicol Lett 1998;41:107-14. 
51. Abou-Seif MA. Blood antioxidant status and urine sulfate and thiocyanate levels in smokers. J Biochem Toxicol 1996;11:133-8.

52. Hilbert J, Mohsenin V. Adaptation of lung antioxidants to cigarette smoking in humans. Chest 1996;110:916-20.

53. Toda N, Toda H. Nitric oxide-mediated blood flow regulation as affected by smoking and nicotine. Eur J Pharm 2010;649:113.

54. Wei T, Chen C, Hou J, Xin W, Mori A. Nitric oxide induces oxidative stress and apoptosis in neuronal cells. Biochim Biophys Acta 2000;1498:72-9.

55. Aydın A, Orhan H, Sayal A, Özata M, Şahin G, Işımer A. Oxidative stress and nitric oxide related parameters in type II diabetes mellitus: effects of glycemic control. Clin Biochem 2001;34:65-70

56. Andersen MR, Walker LR, Stender S. Reduced endothelial nitric oxide synthase activity and concentration in fetal umbilical veins from maternal cigarette smoking. Am J Obstet Gynecol 2004;191:346-51.
57. Andersen MR, Simonsen U, Uldbjerg N, Aalkjaer C, Stender S. Smoking cessation early in pregnancy and birth weight, length, head circumstance, and endothelial nitric oxide synthase activity in umbilical and chorionic vessels: An observational study of healthy singleton pregnancies. Circulation 2009;119:857-64.

58. Dani C, Giannini L, Bertini G, Pratesi S, Corsini I, Longini M, Buonocore G, Masini E, Rubaltelli FF. Changes of nitric oxide, carbon monoxide and oxidative stress in term infants at birth. Free Radic Res 2007;41:1358-63.

59. Keen CL, Clegg MS, Ferrell F, Hunter GC, Dubick MA. Hypertension induced alterations in copper and zinc metabolism: a link to vascular disease? In: Sorenson JRJ, editors. Biology of copper complexes. Clifton (NJ): Humana Press; 1987. p. 141-50.

60. Dubick MA, Keen CL. Influence of nicotine on tissue trace element concentrations and tissue antioxidant defense. Biol Trace Elem Res 1991;31:97-109. 


\section{Sažetak}

\section{ŠTETNI UČINCI PUŠENJA TIJEKOM TRUDNOĆE NA DNA I RAZINE REAKTIVNIH OBLIKA KISIKA (ROS) U KRVI MAJKE I NOVOROĐENČETA}

Pojedine genotoksične/kancerogene supstancije ili metaboliti u cigaretnom dimu mogu proći kroz posteljicu i naštetiti zdravlju novorođenčeta. Pušenje je također poznato kao čimbenik pri nastanku oksidacijskog oštećenja DNA i u procesu kancerogeneze. Ovaj genotoksični rizik može se uspješno odrediti mjerenjem određenih parametara oksidacijskog stresa. Komet-test smatra se važnim biološkim biljegom pri evaluaciji genotoksičnih supstancija i iznimno učinkovitim sredstvom pronalaženja oštećenja DNA uzrokovanih pušenjem. Ova studija proučava krv trudnica u trećem tromjesečju trudnoće i fetalnu krv 28 majki aktivnih pušačica te 22-ju majki nepušačica vezano za oksidacijska oštećenja DNA i parametre oksidacijskog stresa. Razine $\mathrm{Cu} / \mathrm{Zn}$ superoksidne dismutaze (CuZn-SOD), malondialdehida (MDA), katalaze (CAT), nitrita/ nitrata u plazmi $\left(\mathrm{NO}_{2}^{-} / \mathrm{NO}_{3}^{-}\right.$), selenijeve glutation peroksidaze (Se-GPx), Cu i $\mathrm{Zn}$ mjerene su kao pokazatelji oksidacijskog oštećenja. Nije bilo značajnih povećanja oštećenja DNA u skupini trudnica aktivnih pušačica u usporedbi sa skupinom trudnica nepušačica, ni u krvi iz trećeg tromjesečja ni u fetalnoj krvi. Parametri oksidacijskog stresa pušačke i nepušačke skupine bili su statistički različiti za vrijednosti $\operatorname{MDA}(\mathrm{p}<0,05)$, CuZn-SOD ( $<<0,01)$, Se-GPx $(\mathrm{P}<0,05)$, dok razlika nije bila značajna za vrijednosti $\mathrm{NO}_{2}^{-} / \mathrm{NO}_{3}^{-}, \mathrm{CAT}, \mathrm{Zn}$ i Cu. Iste su vrijednosti ispitane i u fetalnoj krvi, a jedino su vrijednosti $\mathrm{NO}_{2}^{-} / \mathrm{NO}_{3}^{-}(\mathrm{p}<0,01)$, Se-GPx $(\mathrm{p}<0,01)$ i CAT $(\mathrm{p}<0,001)$ bile statistički različite. Vjerojatno je da su majke pušačice bile izložene većem oksidacijskom stresu od majki nepušačica.

KLJUČNE RIJEČI: cigaretni dim, fetalna krv, genotoksičnost, oksidacijski stres, trudnice

\section{CORRESPONDING AUTHOR:}

Dr İsmet Çok

Faculty of Pharmacy

Department of Toxicology, Gazi University

06330 Hipodrom/Ankara, TURKEY

Email: ismetc@gazi.edu.tr 